\title{
PECTINASE PRODUCTION AND CLARIFICATION TREATMENTS OF APPLE (MALUS DOMESTICA) JUICE
}

\author{
Cocok Ana Maryani B ${ }^{1}$, Fahrurrozi ${ }^{2}$, Anja Meryandini ${ }^{3 *}$ \\ ${ }^{1}$ Department of Biotechnology, Graduate School of Bogor Agricultural University, Dramaga \\ Campus, Bogor 16680, Indonesia. \\ ${ }^{2}$ Research Center for Biotechnology, Indonesian Institute of Sciences, Cibinong 16911, Indonesia. \\ ${ }^{3}$ Department of Biology, Faculty of Mathematics and Natural Sciences Bogor Agricultural \\ University, Dramaga Campus, Bogor 16680, Inodnesia.
}

\begin{abstract}
Pectinases are a group of enzymes that break down pectin, a polysaccharide that is found in plant cell walls. Today, the application of pectinolytic enzymes plays an important role in food technology for the maceration of fruits and vegetables, including for the extraction and clarification of juice. This research aimed to produce pectinase enzyme for clarifying apple juice. A microbial culture was selected from cocoa bean fermentation samples and identified as Bacillus sp.. Citrus pectin (1\%) as the carbon source and peptone $(0.1 \%)$ as the nitrogen source was found as the best component for pectinase production. The optimum condition of pectinase activity was observed at $\mathrm{pH} 5$ and temperature $40{ }^{\circ} \mathrm{C}$. Enzyme stability studies were performed by incubating crude extract at and the crude enzyme at $40{ }^{\circ} \mathrm{C}$ and the percentage activity decrease after one hour storage. Apple juice was treated with the enzyme at different concentrations $(0 \%, 0.5 \%, 1 \%, 2 \%, 4 \%)$. Apple juice clarification was evaluated for its percent clarity and viscosity. The result showed that enzyme treatment at $4 \%$ in apple juice promoted juice clarification and decreased $\mathrm{pH}$ value. In conclusion, the quality of apple juice can be improved by enzymatic treatment using pectinase.
\end{abstract}

Keywords: Bacillus, clarification, apple juice, pectinase

*Corresponding author: Anja Meryandini

Department of Biology, Faculty of Mathematics and Natural Sciences Bogor Agricultural University, Dramaga Campus, Bogor 16680, Indonesia

Telp. +62-251-8622833

E-mail. ameryandini@ipb.ac.id

\section{Introduction}

Pectinases are a group of an enzyme capable of hydrolyzing pectin substances or degrading molecules that are found in the middle lamella and primary cell walls of plants. Various microbes have been reported to produce pectinase, such as filamentous fungi including Aspergillus sp. (Reddy \& Sreeramulu, 2012), bacteria including Bacillus sp. (Aaisha \& Barate, 2015), and yeast including Aureobasidium pullulans (Merin et al., 2011).

Currently, pectinase production has been widely applied in various industrial fields, such as the food industry (processed fruit and vegetable products), wine industry, extraction of olive oil, fermented tea, coffee and cocoa, sewage treatment and paper production
(Kashyap et al., 2001). Due to increase in demands for human needs, studies on pectinase producing microbes have gained tremendous attention for the production of potential pectinase.

Fruits have been one of the high-value agricultural commodities for the beverage industry in the agribusiness system around the world (Retnowati et al., 2008). Apples (Malus domestica) have been processed into apple juice. USDAFAS (2017) reported that apple production was increased since last 5 years from 71635 tons to 77165 tons. In general, fruit juice was produced through three stages of extraction, clearance, and stabilization. Pectinase plays an important role in the process of extracting and purifying the juice. Kashyap et al. (2001) reported that enzymatic hydrolysis of fruit tissue walls containing pectin at the extraction and purifying process 
was able to decrease turbidity and viscosity. In the other hand, enzymatic hydrolysis of the cell wall increases clarity and nutritional value (sugar, vitamins, galactic acid and antioxidants) in the juice (Arsad et al., 2015; Sharma et al., 2014). In its application, optimization of pectin hydrolysis is influenced by several factors, including incubation temperature, enzyme concentration and the combination of other enzymes (Sharma et al., 2014). Studies on production of pectinase are important to develop enzyme systems which could be directly used for converting various carbon and nitrogen source into enzymes. So, it is necessary to optimize the media production.

Based on this explanation, current work is aimed to produce pectinase from selected Bacillus sp., (code 2P11) isolate obtained from the fermented cocoa peel and seed, to optimize pectinase production, to characterize the pectinase and to investigate its ability in clarification of apple juice.

\section{Materials and Methods}

Microorganism. Bacillus sp. (code 2P11 from Animal Biotechnology Laboratory, Research Center for Bioresources and Biotechnology, Bogor Agricultural University) was isolated from the fermented cocoa peel and seed in Sukabumi, West Java, Indonesia. Pure culture was sub-cultured on slant media and maintained for enzyme studies.

Medium for Pectinase Production. A basic liquid medium modified from Kumar \& Sharma (2012) was used for the production of pectinase with composition $(\mathrm{g} / \mathrm{L})$ as follow; 3 $\mathrm{g}\left(\mathrm{NH}_{4}\right)_{2} \mathrm{SO}_{4}, 4,5 \mathrm{~g} \mathrm{KH}_{2} \mathrm{PO}_{4}, 1 \mathrm{~g}$ yeast extract, $0.25 \mathrm{~g} \mathrm{MgSO}_{4} \cdot 7 \mathrm{H}_{2} \mathrm{O}, 0.25 \mathrm{~g} \mathrm{CaCl}_{2} \cdot 2 \mathrm{H}_{2} \mathrm{O}$, and $10 \mathrm{~g}$ pectin citrus. All these ingredients were dissolved in sterile distilled water and adjusted to $\mathrm{pH}$ 5. Media were sterilized in autoclave at $121{ }^{\circ} \mathrm{C}$ under pressure of 1 atmosphere for 17 min.

\section{Optimization of Carbon and Nitrogen Sources.}

Optimization pectinase production carried out by determining the best carbon and nitrogen source in media production. Different carbon sources (1\%); such as citrus pectin, glucose, galactose, sucrose, fructose and starch were supplemented as individual components to the basal media to check their effect on pectinase production. After the best type of carbon source was determined, optimization of nitrogen sources $(0.1 \%)$ such as $\left(\mathrm{NH}_{4}\right)_{2} \mathrm{SO}_{4}$, peptone, yeast extract, and peptone-yeast extract was performed using the same procedure to found the best nitrogen type. The experiment was carried out in duplo for each carbon and nitrogen types. The production media was incubated in water bath shaker 110 rpm for 48 hours at $30{ }^{\circ} \mathrm{C}$.

Characterization of Crude Enzyme Activity. Enzyme characterization was performed to determine optimum $\mathrm{pH}$ and temperature and its stability (Joshi et al., 2015). The optimum $\mathrm{pH}$ was determined by measuring enzyme activity at various $\mathrm{pH}$ (acetate buffer $\mathrm{pH}$ 3-7), while the determination of optimum temperature was carried out at temperature levels of $30,40,50$, 60 and $70{ }^{\circ} \mathrm{C}$. Determination of enzyme stability time was performed by testing the enzyme activity at optimum $\mathrm{pH}$ and temperature. Crude extract sample was taken to a water bath by optimum temperature of enzyme for several hours and every one hour the enzyme assayed until its activity decreased.

Determination of Enzyme Activity. The enzyme activity was measured using DNS method as prescribed by Miller (1959) with modification. Culture media was centrifuged at $8500 \mathrm{rpm}$ and supernatant was used as crude enzyme and was prepared for assay. Crude enzyme extract $(1000 \mu \mathrm{L})$ was mixed with acetate buffer $0.05 \mathrm{M}, \mathrm{pH} 5.0,9000 \mu \mathrm{L}$ and $1 \%$ pectin substrate $1000 \mu \mathrm{L}$. The mixture was incubated in water bath shaker at $30{ }^{\circ} \mathrm{C}$ for 5 min. The activity of the enzyme was stopped by mixing $1000 \mu \mathrm{L}$ of sample with $1000 \mu \mathrm{L}$ of DNS, then incubated in water bath at $100{ }^{\circ} \mathrm{C}$ for $5 \mathrm{~min}$. Test control prepared as same as test sample mixture without incubation time. Blanks containing only the substrate solution were also prepared. All samples absorbance value was measured by spectrophotometer at $540 \mathrm{~nm}$ wavelength. The measurement was based on the amount of reducing sugar and galacturonic acid as standard. One unit of pectinase activity is defined as the amount of enzyme needed to break down pectin to one $\mu$ mol of galacturonic acid per min under experimental conditions of enzyme activity (Qureshi et al., 2012). 
Clarification of Apple Juice using Pectinase. Apple juice clarification was evaluated for its $\mathrm{pH}$, clarity and viscosity. One kilogram apples were washed, dried, cut (cube cuts) and crushed using a juice processor to produce juice. The apple juice was then transferred into a bottle and incubated in water bath at $85{ }^{\circ} \mathrm{C}$ for $5 \mathrm{~min}$ (Arsad et al., 2015). The apple juice $(50 \mathrm{~mL})$ was stored in the bottle and five different enzymatic treatments were used (I: apple juice without enzyme treatment as control, II: apple juice was added $0.5 \%$ enzymes (activity $118.51 \mathrm{mU} / \mathrm{mL}$ ), III: apple juice was added $1 \%$ enzymes (activity 329.07 $\mathrm{mU} / \mathrm{mL}$ ), IV: apple juice was added $2 \%$ enzymes (activity $509.60 \mathrm{mU} / \mathrm{mL}$ ), and $\mathrm{V}$ : apple juice was added 4\% enzymes (activity $999.46 \mathrm{mU} / \mathrm{mL}$ ). Pectinase-treated apple juice was then incubated in water bath at $40{ }^{\circ} \mathrm{C}$ for 1 hour. To inactivate enzymatic reaction, the bottle was heated at $90{ }^{\circ} \mathrm{C}$ for $5 \mathrm{~min}$. The $\mathrm{pH}$ measurements were performed using a $\mathrm{pH}$ meter, the clarity of the juice obtained was determined by measuring the absorbance at a wavelength of $660 \mathrm{~nm}$ using spectrophotometer and distilled water was used as the reference. The viscosity was measured by a Ostwald viscometer and distillated water was used a reference. Time required to flow through the capillary section of the Ostwald viscometer was noted using a stopwatch for the reference. All the experiment were carried out in triplicate. Statistical significants differences of mean were analysis by ANAVA using software SPSS 17.0

\section{Results and Discussion}

\section{Optimization of Pectinase Production Media.}

The increase in high activity production requires a range of optimization stages, including the types of carbon and nitrogen sources that are important factors in the growth and production of enzymes (Sumantha et al., 2006). The effect of parameters such as $\mathrm{pH}$ and temperature of fermentation was chosen based on the cocoa pulp fermentation condition ( $\mathrm{pH} 5$ and room temperature, $30^{\circ} \mathrm{C}$ ). Among several types of carbon sources used, citrus pectin resulted in the highest enzyme activity $(734.38 \mathrm{mU} / \mathrm{mL})$ in Bacillus sp. isolate, and its activity decreased on the use of galactose, sucrose, fructose and starch (Figure 1a). Prakash et al. (2010) and Ranveer et al.
(2010) also reported that citrus pectin was the best source of carbon in Bacillus subtilis and Bacillus sphaericus. Peptone and combination of peptone-yeast extract as a source of nitrogen in the fermentation medium resulted in the highest enzyme activity, which was 787.12 $(\mathrm{mU} / \mathrm{mL})$ and $767.37(\mathrm{mU} / \mathrm{mL})$, respectively. Enzyme activity decreased to $48 \%$ when $\left(\mathrm{NH}_{4}\right)_{2} \mathrm{SO}_{4}$ was used as a nitrogen source (Figure 1b).

a)

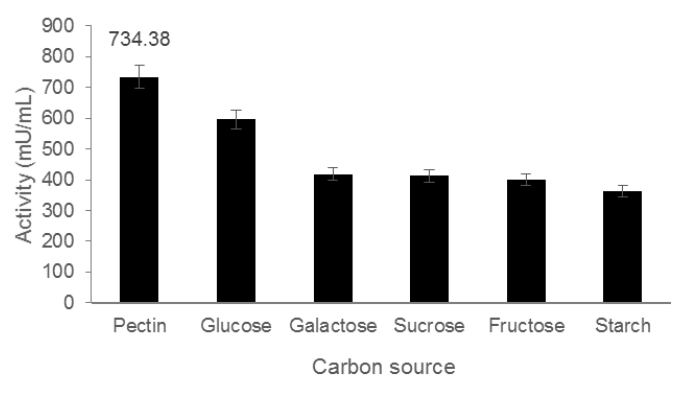

b)

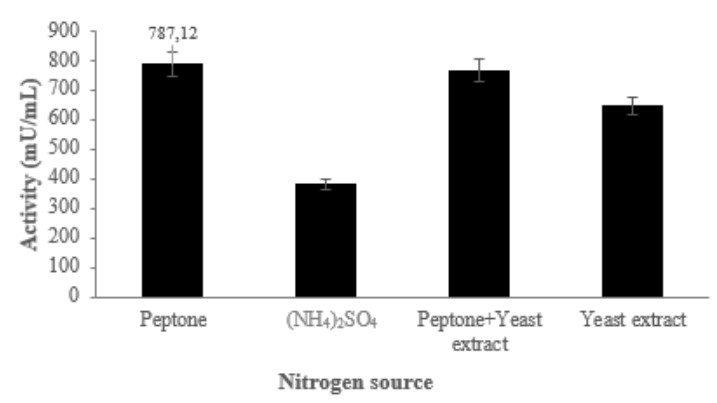

Figure 1. Effects of carbon sources (1\%) (a), nitrogen sources $(0.1 \%)$ (b) on pectinase production assayed at condition $\mathrm{pH} 5$ and temperature $30^{\circ} \mathrm{C}$.

\section{Characterization of Enzyme Activity.}

Citrus pectin $(1 \%)$ and peptone $(0.1 \%)$ were selected for optimum production media. This study was continued by characterizing the enzyme activity such as $\mathrm{pH}$, temperature, and time stability. Characterization of $\mathrm{pH}$ as depicted in Figure 2 indicated that optimum condition $(825.64(\mathrm{mU} / \mathrm{mL})$ of pectinase from Bacillus sp. was observed at pH 5.0 and below this $\mathrm{pH}$, pectinase activity declined. Ray et al., (2011) reported that pectinases have different optimum $\mathrm{pH}$ depends on microorganism in nature and generally there were between 4 to 9 value, such as Paenibacillus xylanolyticus optimum at $\mathrm{pH} 9$ (Giacobbe et al., 2014), pectinase from Bacillus halodurans $\mathrm{M} 29$ at $\mathrm{pH}$ 10 (Mei et al., 2013), pektat liase from Bacillus pumilus DKS1 at pH 7 (Santner et al., 
2006), and pektat liase from Bacillus sp. RN1 at pH 7 (Sukhumsiirchart et al., 2009).

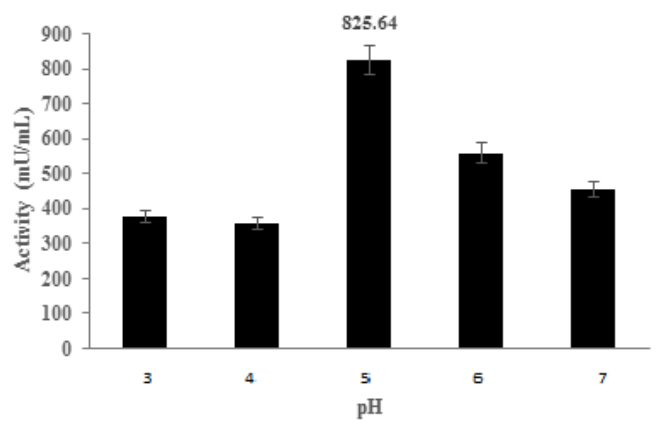

Figure 2. Effects of $\mathrm{pH}$ on enzyme activity assayed at temperature of $30^{\circ} \mathrm{C}$.

Figure 3 showed that activity of pectinase from Bacillus sp. was optimum (997.48 $(\mathrm{mU} / \mathrm{mL}))$ at $40{ }^{\circ} \mathrm{C}$. The decrease in pectinase activity was observed in the higher temperatures such as $60{ }^{\circ} \mathrm{C}(378.25 \mathrm{mU} / \mathrm{mL})$ and $70{ }^{\circ} \mathrm{C}(187.64 \mathrm{mU} / \mathrm{mL})$. Manashi et al. (2014) and Kashyap et al. (2000) reported that pectinase produced by Bacillus subtilis showed optimum activity at $\mathrm{pH} 5.0$ and $40{ }^{\circ} \mathrm{C}$. Data related to the effects of $\mathrm{pH}$ and temperature on pectinase activity investigated in this current work are meaningful in the determination of processing condition using particular substrate.

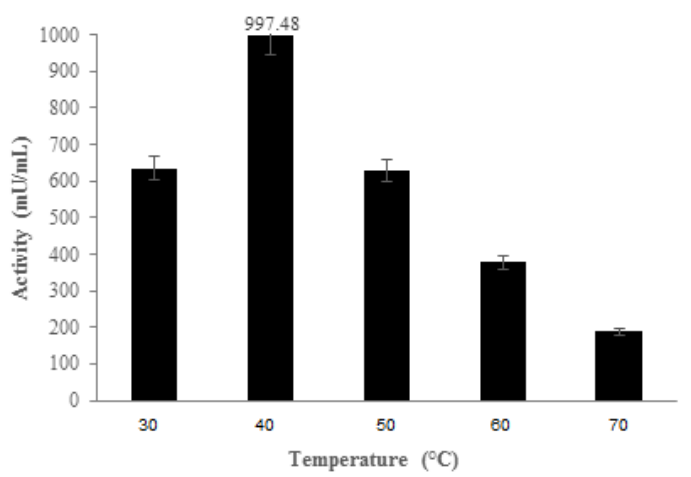

Figure 3. Effects of temperature on enzyme activity.

Enzyme activity is affected by $\mathrm{pH}$ and environment temperature in which the enzyme works. The $\mathrm{pH}$ and temperature that are too far from its optimum condition may lead to enzyme denaturation, leading to a reduction of its activity.

Determination of pectinase stability time is to understand the enzyme survival after harvested. Crude enzyme that placed in water bath with temperature of $40{ }^{\circ} \mathrm{C}$ had enzyme activity as $100 \%$ at 0 hour and decreased to $48.55 \%$ with an increased time of storage in four hours. This suggests that longer storage duration was responsible for higher pectinase denaturation.

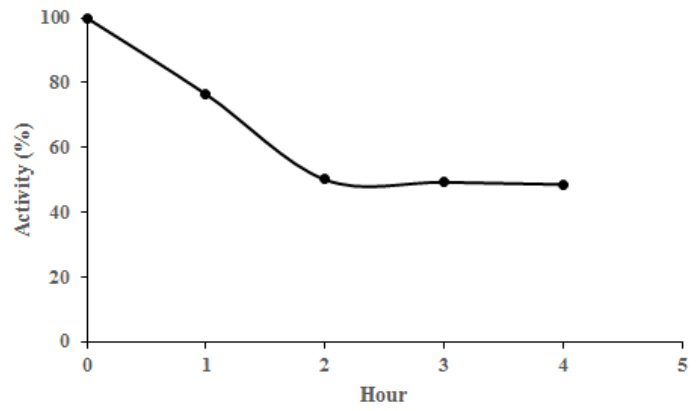

Figure 4. Effects of time storage on enzyme activity assayed at temperature of $40{ }^{\circ} \mathrm{C}$.

Based on percentage stability of activity, the conformation of the enzyme structure may be caused by denaturation enzyme after two hour until four hour storage.

\section{Clarification of Apple Juice using Pectinase.}

Table 1 shows the difference result of $\mathrm{pH}$, viscosity, and clarity between apple juice without enzyme additions and apple juice with enzymes treatment. Based on the analysis, apple juice with $0.5 \%, 1 \%, 2 \%$ and $4 \%$ pectinase treatment have significantly different to the control although there was no significant change in another treatment. The addition of pectinase in apple juice decreased the $\mathrm{pH}$ value. According to Acar et al., (1999) treated juice became more acidic, indicating that the enzyme able to hydrolyze the pectin polymer in solution into its monomer form named galacturonic acid. The pectinase concentration of $4 \%$ in apple juice treatment resulted the lowest $\mathrm{pH}$ value of 4.07. According to Acar et al. (1999), the decrease in $\mathrm{pH}$ is due to the increasing amount of galacturonic acid content which is the result of pectin hydrolysis by pectinase which is causing apple juice more acidic.

The viscosity of apple juice higher than water viscosity $(1 \mathrm{cP})$. The viscosity value of apple juice with the addition of pectinase was significantly different from the apple juice without of pectinase treatment. Table 1 shows that the more pectinase added, the less viscovity value was obtained, although between the treatments have no significant difference. The pectinase with $4 \%$ 
concentration yields the lowest viscosity of apple juice that is $1.837 \mathrm{cP}$. Based on these results, $4 \%$ pectinase was only able to decrease the viscosity of apple juice by $6.99 \%$ which is higher amounts of enzyme may be effectively reduce the viscosity of the juice. Dey et al. (2014) reported that the results of apple juice clarification using purification polygalacturonase from Aspergillus awamori Nakazawa MTCC 6652 was able to decrease viscosity to $38 \%$.

The measurement of the clarity of the apple juice was observed by decreasing the optical density measured using a spectrophotometer, where the lowest absorbance value indicated the clearest result of the fruit juice. The lowest absorbance value was in the $4 \%$ pectinase treatment of 0.097 which was had significantly different from the other treatments. Based on these results $4 \%$ pectinase can increase clarity of apple juice by $42.6 \%$.

Alvarez et al., (1998) reported that during the incubation in apple juice treatment, the pectinase (In this experiment used Pectinex $3 \mathrm{XL}$, activity $3000 \mathrm{FDU}^{1 /} / \mathrm{mL}$ ) break down the pectin polymer in solution which ultimately increased the formation of pectin and protein into clots, resulting in a clearer fruit juice supernatant.

The potential of pectinase produced by bacterial was found in clarifying the others juice fruit such as lemon (Widowati et al., 2014) and mango (Iriani et al., 2005).

Table 1. Effects of enzyme concentration on $\mathrm{pH}$, viscosity, and clarity of apple juice.

\begin{tabular}{cccc}
\hline Treatment & $\mathbf{p H}$ & $\begin{array}{c}\text { Viscosity } \\
(\mathbf{s P})\end{array}$ & Clarity \\
\hline $\begin{array}{c}\text { Control } \\
\text { (Untreated) }\end{array}$ & $4.17 \pm 0.02^{\mathrm{a}}$ & $1.975 \pm 0,1^{\mathrm{a}}$ & $0.169 \pm 0.01^{\mathrm{c}}$ \\
Pectinase 0.5\% & $4.11 \pm 0.005^{\mathrm{b}}$ & $1.878 \pm 0.05^{\mathrm{a}}$ & $0.133 \pm 0.01^{\mathrm{b}}$ \\
& & & \\
Pectinase 1\% & $4.10 \pm 0.01^{\mathrm{b}}$ & $1.866 \pm 0,05^{\mathrm{a}}$ & $0.123 \pm 0.02^{\mathrm{ab}}$ \\
& & & \\
Pectinase 2\% & $4.09 \pm 0.005^{\mathrm{b}}$ & $1.846 \pm 0,02^{\mathrm{a}}$ & $0.118 \pm 0.01^{\mathrm{ab}}$ \\
& & & \\
Pectinase 4\% & $4.07 \pm 0.04^{\mathrm{b}}$ & $1.837 \pm 0,08^{\mathrm{a}}$ & $0.097 \pm 0.004^{\mathrm{a}}$
\end{tabular}

*Data are mean \pm SE $(n=3)$. Means with the same superscript within a column are significantly difference $(\mathrm{p}<0.05)$.

The application of pectinase in improving the quality of apple juice is still relatively low compared to the commercial enzyme
Novozym 33095 (Poletto et al., 2015) which can increase clarity up to $80 \%$ and reduce viscosity up to $40 \%$. Arsad et al., (2015) reported that the viscosity value of juice can decrease significantly by combining pectinase and other enzyme types, such as cellulose. In addition, it is thought that the need to add pectinase concentrations in this experiment so that the clarity is more optimal and the viscosity value is significantly different from the control.

\section{Conclusion}

The use of citrus pectin as a carbon source and peptone as a nitrogen source in the medium can enhance Bacillus sp. pectinase enzyme activity. The pectinase obtained demonstrated the optimum activity at $\mathrm{pH} 5$ and $40{ }^{\circ} \mathrm{C}$ and showed stability for one hour. In clarification treatment, pectinase concentration of $4 \%$ was capable of reducing $\mathrm{pH}$ by 4.07 and increasing the clarity of apple juice by $42.6 \%$.

\section{Acknowledgments}

Authors are grateful to Lembaga Pengelola Dana Pendidikan (LPDP), Indonesia for funding this research.

\section{References}

Acar, J., Alper, N., \& Esturk, O. (1999). The Production of Cloudy Apple Nectar using Total Liquefaction Enzymes. Fruit Process, 8: 314-317.

Aaisha, G.A., \& Barate, D.L. (2015). Isolation and Identification of Pectinolytic Bacteria from Soil Samples of Akola Region, India. Int J of Currebt Microbiology and Applied Sciences, 5(1): 514-521.

Alvarez, S., Alvarez, R., Riera, F.A., \& Coca, J. (1998). Influence of Depectinization on Apple Juice Ultra-filtration Colloidal and Surface. Physicochemical and Engineer Aspect, 138: 337-382.

Arsad, P., Sukor, R., Wan, I.W.Z., Mustapha, N.A, \& Meor, A.S. (2015). Effect of Enzymatic Treatment on Physicochemical Properties of Sugar Palm Fruit Juice. Int J on Adv Science Engineering Information Technology, 5: 308312. 
Dey, T.B., Adak, S., Bhattacharya, P., \& Banerjee, R. (2014). Purification of Polygalacturonase from Aspergillus awamori Nakazawa MTCC 6652 and Its Application in Apple Juice Clarification. Food Sci Technol, 59: 591-595.

Iriani., E.S., Said, E.G., Suryani, A., \& Setyadjit. (2005). Pengaruh Konsentrasi Penambahan Pektinase dan Kondisi Inkubasi terhadap Rendemen dan Mutu Jus Mangga Kuini (mangifera odorata Griff). J Pascapanen, 2(1): 11-17.

Joshi, M., Nerurkar, M., \& Adivarekar R. (2015). Characterization,Kinetic, and Thermodynamic Studies of Marine Pectinase From Bacillus subtilis. Preparative Biochem \& Biotech, 45: 205-220.

Kashyap, D.R., Chandra, S., Kaul, A., \& Tewari, R. (2000). Production, Purification and Characterization of Pectinase from a Bacillus sp. DT7. World J Microbiol Biotechnol, 16: 277-282.

Kashyap, D.R., Vohra, P.K., Chopra, S., \& Tewari, R. (2001). Application of Pectinase in the Commercial Sector: a review. Bioresour Technol, 77: 215-227.

Kumar, A., \& Sharma, R. (2012). Production of alkaline pectinase by bacteria (Cocci species) isolated from decomposing fruit materials. $J$. Phytol, 4 (1): 1-5.

Manashi, J., Madhur, N., \& Ravindra, A. (2015). Characterization, Kinetic and Thermodynamic Studies of Marine Pectinase from Bacillus subtilis. Preparative Biochem and Biotech, 45: 205-250.

Mei, Y., Chen, Y., Zhai, R., \& Liu, Y. (2013). Cloning, Purification and Biochemical Properties of a Thermostable Pectinase from Bacillus halodurans M29. J of Molecular Catalys B: Enzymatic, 94: 77-81.

Merin, M.G., Mendoza, L.M., Farias, M.E., \& de Ambrosini, V.I.M. (2011). Isolation and selection of yeasts from wine grape ecosystem secreting cold-active pectinolytic activity. Int J of Food Microbiology, 147: 144-148.

Miller, G.L. (1959). Use of Dinitrosalicylic Acid Reagent for Determination of Reducing Sugar. Analytical Chemistry, 31 (3): 426-428.

Poletto, P., Borsoi, C., Zeni, M., \& da Silveira, M.M. (2015). Downstream Processing of Pectinase Produced by Aspergillus niger in Solid State Cultivation and its Application to fruit Juices Clarification. Food Sci Technol, 35(2): 391-397.

Prakash, S., Karthik, R., Tamil, V.M., Sridhar, B., \& Bharath, P.G. (2014). Optimization and Production of Pectinase from Bacillus Subtilis (MTCC 441) using Orange Peel as a Substrate. Int J of Science and Research, 5 (6): 1177-1179.
Qureshi, A.S., Bhutto, M. A., Chisti, Y., Khushk, I., Dahot, M. U., \& Bano, S. (2012). Production of Pectinase by Bacillus subtilis EFRL 01 in a date syrup medium. African $J$ of Biotech, 11(62): 12653012570.

Ranveer, S.J, Surendra, K.S., \& Reena, G. (2010). Screening of Bacterial Strains for Polygalacturonase Activity: Its Production by Bacillus sphaericus (MTCC 7542). Enzyme Research: 1-5.

Reddy, P.L., Sreeramulu, A. (2012). Isolation, identification and screening of pectinolytic fungi from different soil samples of chittoor district. Int J of Life Sciences Biotechnology and Pharma Research, 1(3): 186-193.

Retnowati, D.S., Kumoro, A.C., Bidiarti, C.S. (2008). Modeling on Rheological Properties of Tropical Fruit Juices. RSCE-SOMCHE: 851-856.

Santner, B.G.K., Schnitzhofer, W., Vrsanska, M., Weber, J., Agrawal, P.B., Nierstrasz, V.A., \& Guebitz, G.M. (2006). Purification and Characterization of a New Bioscouring Pectate Lyase from Bacillus pumilus BK2. J of Biotechnol, 121: 390-401.

Sharma, H.P., Hiral, P., Sharma, S. (2014). Enzymatic Extraction and Clarification of Juice from Various Fruits-A Review. Trend in Post Harvest Technology, 2 (1), 01-14.

Sukhumsiirchart, W., Kawanishi, S., Deesukon, W., Chansiri, K., Kawasaki, H., Sakamoto, T. (2009). Purification, Characterization, and Overexpression of Thermophilic Pectate Lyase of Bacillus sp. RN1 Isolated from a Hot Spring in Thailand. Biosci, Biotchnol, Biochem, 73(2): 268-273.

Sumantha, A., Larroche, C., \& Pandey, A. (2006). Microbiology and Industrial of Foodgrade Proteases: A perspective. Food Technology Biotechnology, 44 (2): 211-220.

United States Departement of Agriculture Foreign Agricultural Service (USDA-FAS). (2017). Fresh Deciduous Fruit: World Markets and Trade (Apples, Grapes, \& Pears). Retrieved on June 20, 2017 from USDA website: http://www.nass.usda.gov/Newsroom/Notices/ 2016/01_07_2016.php.

Wang, B., Cheng, F., Lu, Y., Ge, W., Zhang, M., \& Yue, B. (2013). Immobilization of pectinase from Penicillium oxalicum F67 onto Magnetic Cornstarch Microspheres: Characterization and Application in Juice Production. $\mathrm{J} \mathrm{Mol}$ Cat B Enz, 97: 137-143.

Widowati, E., Utami., R Nurhartadi, E., Andriani, M.A.M., \& Hanifah, R. (2014). Produksi dan Karakterisasi Enzim Pektinase Bakteri Pektinolitik dari Limbah Kulit Jeruk untuk Klarifikasi Jus Lemon (Citrus limon). J Teknologi Hasil Pertanian, 7(1). 